\title{
Fat and fatty acid composition of hazelnut kernels in vacuum packages during storage
}

\author{
By Mehmet Ali Koyuncu ${ }^{1^{*}}$, Ali Islam ${ }^{2}$, Mehmet Küçük ${ }^{3}$ \\ ${ }^{1}$ Department of Horticulture, Faculty of Agriculture, Suleyman Demirel University, \\ 32260 Isparta-TURKEY. Fax: +90-246-2371693; E-mail address: mkoyuncu@ziraat.sdu.edu.tr \\ ${ }^{2}$ Department of Horticulture, Faculty of Agriculture, Karadeniz Teknik University, \\ 52100 Ordu-TURKEY \\ ${ }^{3}$ Department of Food Engineering, Faculty of Agriculture, Yüzüncü Yil University, \\ 65100 Van-TURKEY
}

\section{RESUMEN}

Contenido en grasa y composición en ácidos grasos de semillas de avellana empaquetadas al vacío durante su almacenamiento.

El contenido en grasa y la composición en ácidos grasos de tres cultivares de avellana (Tombul, Palaz y Kalinkara) han sido monitorizados durante su almacenamiento a $21^{\circ} \mathrm{C}$ y una humedad relativa del 60-65\%. Los porcentajes de grasa total de las semillas empaquetadas al vacío aumentaron significativamente con el tiempo de almacenamiento. Ello se cree que es debido no a que el valor absoluto de contenido graso aumente, sino a que disminuye el contenido en agua de la semilla y su peso total. Los porcentajes de ácidos palmítico y oleico aumentan en las avellanas almacenadas, mientras que el porcentaje de linoleico descendíó. No se hallaron diferencias significativas en los porcentajes de los ácidos esteárico y linoleico durante el almacenamiento.

PALABRAS-CLAVE: Almacenamiento - Avellanas . Composición en ácidos grasos - Contenido graso - Empaquetado al vacío.

\section{SUMMARY}

Fat and fatty acid composition of hazelnut kernels in vacuum packages during storage.

The fat contents and fatty acid compositions of three hazelnut cultivars; Tombul, Palaz and Kalinkara were investigated during storage at $21^{\circ} \mathrm{C}$ with $60-65 \%$ relative humidity. The total fat contents of kernels in vacuum packages increased significantly with storage time. It is believed that the absolute value of fat content does not increase but that the kernel water content and total weight decrease. The palmitic and oleic acid contents of stored hazelnuts increased, while linoleic acid content decreased. No significant differences were found for stearic and linolenic acids during storage.

KEY-WORDS: Fat content - Fatty acid composition Hazelnuts - Storage - Vacuume package.

\section{INTRODUCTION}

Hazelnuts (Corylus avellana L.) are mainly produced in Turkey followed by Italy, USA and Spain (FAO, 2003). The Black Sea region is the principal hazelnut producing state in Turkey. Besides their economic value, hazelnuts provide a definite flavor to food products and play a major role in human nutrition and health (Özdemir et al., 2001). People who consumed nuts five or more times a week had a $50 \%$ reduced risk of coronary heart disease relative to those who never consumed nuts (Fraser et al., 1992). Similar results about the effect of hazelnuts on human health were also reported in different studies (Ebrahem et al., 1994; Koyuncu et al., 1997; Savage and McNeil, 1998). This positive effect of hazelnuts depends on their fatty acid composition, especially unsaturated fatty acid (Garcia et al., 1994). Savage and McNeil (1998) indicated that hazelnut quality depends primarily on the composition of the lipid content which makes up $60-70 \%$ of the dry weight of the kernel. Therefore, we have to know the changes in fat content and fatty acid composition of hazelnuts during storage. Little data is available on the change in the lipid profile of hazelnuts during storage (Agar et al., 1995), but there is no study on the change in fat contents and fatty acid compositions of Tombul, Palaz and Kalinkara kernels in vacuum packages at $21^{\circ} \mathrm{C}$.

\section{EXPERIMENTAL}

\subsection{Plant Material}

The nuts of three different hazelnut varieties (Tombul, Palaz and Kalinkara) were obtained from an orchard in the Giresun district of the Black Sea region of Turkey. About 350 hazelnuts per plant were collected at random from fifteen different trees to make up the representative samples of each variety. After harvest, the samples were dried in the dark at $22-25 \mathrm{C}$ with $40-50 \%$ relative humidity. Kernels were collected at the date of harvest maturity and dried kernels were stored in vacuum bags of $500 \mathrm{~g}$ capacity at $21^{\circ} \mathrm{C}$ with $60-65 \%$ of relative humidity $(\mathrm{RH})$ for 12 months. The fat content and fatty acid compositions of kernels were determined in three 
stages (at the beginning and after the sixth and twelfth month) during the storage period. For each hazelnut lipid sample three transesterifications were performed and all the obtained samples were analyzed in duplicate using gas chromatography.

\subsection{Total fat content}

The total fat content was determined as a percentage by a soxhlet apparatus using solvent in accordance with the AOAC method 948.22 (AOAC, 2000).

\subsection{Fatty acid composition}

Fatty acid methyl ester (FAME) was prepared from the oil according to Parcerisa et al. (1998). 200 $\mathrm{mg}$ of hazelnut oil was saponified with $3 \mathrm{ml}$ of sodium methoxide in methanol $\left(0.5 \mathrm{~mol} \mathrm{I}^{-1}\right)$ at $100^{\circ} \mathrm{C}$ in a water bath for $10 \mathrm{~min}$; the solution was cooled to room temperature and $2 \mathrm{ml}$ of $12 \%(\mathrm{w} / \mathrm{v})$ boron trichloride in methanol was added. The solution was heated for a further $10 \mathrm{~min}$ in a boiling water bath. After cooling, $1 \mathrm{ml}$ of hexane was added and the mixture was shaken vigorously. Then $1 \mathrm{ml}$ of $0.6 \%$ $(w / v)$ of sodium chloride was added. The organic layer was transferred to a screw-cap test tube with a Pasteur pipette. The organic solution was dried with anhydrous sodium sulphate and filtered. Finally the filtrate was concentrated under a stream of nitrogen. FAMEs were analyzed by GC. The gas chromatographic analysis was performed on a Varian Aerograph equipped with an FID fitted with a column (2m) packed with 15\% DEGS on choromosorb 60-80 mesh. The carrier gas was $\mathrm{N}_{2}$ with a flow rate of $35 \mathrm{~mL} / \mathrm{min}$. The column was run isothermally at $195{ }^{\circ} \mathrm{C}$ and injector and detector were at $220{ }^{\circ} \mathrm{C}$. The fatty acids were identified by the retention time by comparing with standards.

\subsection{Moisture content and weight loss}

The moisture content of a kernel was determined as a percentage according to Anonymous (1978). Each sampling time $50 \mathrm{~g}$ kernel was used for moisture analysis. Weight losses of hazelnuts during the storage period were determined using a digital balance reading to $0.001 \mathrm{~g}$. Packaged hazelnuts $(500 \pm 5 \mathrm{~g})$ were weighed at the beginning of the experiment and after the sixth and twelfth month of storage. The results were expressed as gram loss of initial weight.

\subsection{Statistical analysis}

The data were evaluated statistically using SPSS 10.0 for Windows.

\section{RESULTS AND DISCUSSION}

The kernel moisture content of the hazelnut varieties Tombul, Palaz and Kalinkara decreased during the storage period. These decreases were statistically significant except for Kalinkara (Table 1). It must be taken into account that polyethylene materials for vacuum packaging have water vapor permeability. Similarly, Pekmezci (1983) found that the moisture contents of hazelnut kernels in polyethylene materials changed over a long term storage period.

Weight loss of hazelnuts in a vacuum package increased as a function of storage time for all cultivars. The effect of storage time on weight loss was statistically significant. At the end of the storage period, weight changes in Tombul, Palaz and Kalinkara were $9.99 \mathrm{~g}, 10.88 \mathrm{~g}$ and $10.68 \mathrm{~g}$, respectively (Table 1 ). These changes affected the fat percentage of hazelnuts. In fact, we believe that the absolute values of hazelnut fat contents do not increase with storage.

Table 1 shows the fat contents and fatty acid compositions of hazelnuts during the storage period. At the beginning, cultivars Tombul, Palaz and Kalinkara contained $56.66 \%, 59.50 \%$ and $60.60 \%$ fat, respectively. The predominant saturated fatty acid in hazelnuts was palmitic. While stearic acid changed from $1.28 \%$ (Kalinkara) to $2.26 \%$ (Tombul), traces of palmitoleic acid were identified. The main unsaturated fatty acid was oleic acid with concentrations between $78.52 \%$ and $79.30 \%$. Linoleic acid ranged from $11.70 \%$ to $13.06 \%$. Trace levels of linolenic acid were determined for the three cultivars as in palmitoleic acids. Similar results in fatty acid compositions were obtained for different hazelnut varieties by several authors (Agar et al., 1995; Keme et al., 1983a; b).

During storage, the total fat contents of Tombul, Palaz and Kalinkara increased from $56.66 \%, 59.50$ $\%$ and $60.60 \%$ to $60.42 \%, 62.34 \%$ and $63.57 \%$, respectively. These differences between the beginning and the end of storage were statistically significant in all cultivars (Table 1). It is due, to some degree, to a decrease in kernel water content and total weight. Agar et al. (1995) indicated that the mean fat content of hazelnuts increased from 58.11 to $62.28 \%$ over a 12 month cold storage period. In this research, which was carried out on 15 different varieties, all cultivars showed an increase in their fat contents. The palmitic and oleic acid contents of stored kernels increased, whereas linoleic acid decreased compared to fresh kernels. While the stearic acid contents of Palaz and Kalinkara increased, a reduction was seen in Tombul at the end of the storage time. Differences in palmitic, palmitoleic and linoleic acid contents of cultivars except for palmitic content of Tombul were statistically significant. No significant differences 
Table 1

The Change of Fat Content (\%), Fatty Acid Composition (\%), Moisture content (\%) and Weight (g) of Hazelnut Cultivars During the Storage

\begin{tabular}{|c|c|c|c|c|}
\hline \multirow{2}{*}{ Cultivars } & \multirow{2}{*}{$\begin{array}{l}\text { Fat, fatty acids, } \\
\text { moisture and weight }\end{array}$} & \multicolumn{3}{|c|}{ Storage period } \\
\hline & & Beginning & $6^{\text {th }}$ month & $12^{\text {th }}$ month \\
\hline \multirow[t]{9}{*}{ Tombul } & Fat & $56.66 b$ & $59.62 \mathrm{a}$ & $60.42 \mathrm{a}$ \\
\hline & Palmitic acid ${ }^{\text {ns }}$ & 5.95 & 5.84 & 6.06 \\
\hline & Palmitoleic acid & $0.10 \mathrm{a}$ & $0.07 a b$ & $0.05 b$ \\
\hline & Stearic acid ${ }^{\mathrm{ns}}$ & 2.26 & 2.05 & 2.10 \\
\hline & Oleic acid $^{\text {ns }}$ & 78.80 & 78.74 & 79.85 \\
\hline & Linoleic acid & $11.70 \mathrm{a}$ & $11.37 \mathrm{a}$ & $10.50 \mathrm{~b}$ \\
\hline & Linolenic acid $^{\mathrm{ns}}$ & 0.07 & 0.05 & 0.06 \\
\hline & Moisture & $6.50 \mathrm{a}$ & $6.47 b$ & $6.45 c$ \\
\hline & Weight & $502.27 \mathrm{a}$ & $498.57 \mathrm{a}$ & $492.28 b$ \\
\hline \multirow[t]{9}{*}{ Palaz } & Fat & $59.50 b$ & $59.71 b$ & $62.34 \mathrm{a}$ \\
\hline & Palmitic acid & $6.67 a$ & $6.35 b$ & $6.73 a$ \\
\hline & Palmitoleic acid & $0.05 b$ & $0.50 \mathrm{a}$ & $0.09 b$ \\
\hline & Stearic acid $^{\mathrm{ns}}$ & 1.94 & 2.66 & 2.75 \\
\hline & Oleic acid $^{\mathrm{ns}}$ & 78.52 & 79.91 & 80.86 \\
\hline & Linoleic acid & $12.39 a$ & $9.78 b$ & $10.41 b$ \\
\hline & Linolenic acid $^{\text {ns }}$ & 0.22 & 0.10 & 0.24 \\
\hline & Moisture & $6.0 \mathrm{a}$ & $5.98 a$ & $5.94 b$ \\
\hline & Weight & $504.25 a$ & $499.50 \mathrm{~b}$ & $493.37 c$ \\
\hline \multirow[t]{9}{*}{ Kali nkara } & Fat & $60.60 \mathrm{~b}$ & $63.02 \mathrm{a}$ & $63.57 \mathrm{a}$ \\
\hline & Palmitic acid & $5.28 b$ & $6.75 a$ & $5.70 \mathrm{~b}$ \\
\hline & Palmitoleic acid & $0.07 a$ & $0.05 b$ & $0.02 c$ \\
\hline & Stearic acid ${ }^{\mathrm{ns}}$ & 1.28 & 1.93 & 1.51 \\
\hline & Oleic acid $^{\text {ns }}$ & 79.30 & 78.47 & 80.23 \\
\hline & Linoleic acid & $13.06 \mathrm{a}$ & $14.04 \mathrm{a}$ & $10.10 b$ \\
\hline & Linolenic acid $^{\text {ns }}$ & 0.09 & 0.22 & 0.50 \\
\hline & Moisture $^{\mathrm{ns}}$ & 6.3 & 6.27 & 6.24 \\
\hline & Weight & $502.60 \mathrm{a}$ & $498.75 b$ & $491.92 \mathrm{c}$ \\
\hline
\end{tabular}

Means in the same row with different letters are statistically significant at $\mathrm{P}<0.05 \mathrm{~ns}$, not significant

were found for other fatty acids (Table 1). There is little research related to the fatty acid composition of hazelnuts during the storage period and only in this study, the change in the fatty acid composition of hazelnuts in vacuum packages has been investigated. Literature findings about the changes in the fatty acid compositions of hazelnuts (Koyuncu, 2004) and other nuts such as almonds (Zacheo et al., 2000) and pistachios (Maskan and Karatas, 1998) during storage are in accordance with the results of this research. Agar et al. (1995) indicated that the palmitic and oleic acid contents of hazelnut kernels increased whereas linoleic acid decreased at the end of one year of storage. In the total lipid fraction of almonds, oleic and palmitic acids slightly increased when the fatty acid composition of aged seeds was compared to that of non-aged seeds. Moreover, the concentration of linoleic acid substantially declined (Zacheo et al., 2000).

The totally change in the saturated and unsaturated fatty acid content is given Figure 1. The total saturated fatty acid content of three hazelnut cultivars increased from $7.83 \%$ to $8.21 \%$ at the end of the storage time. On the other hand, the total unsaturated fatty acid content changed from $91.38 \%$ to $90.91 \%$ during this period. These changes were not statistically significant. Kinderlerer and Stuart (1992) indicated that a reduction in degree of 


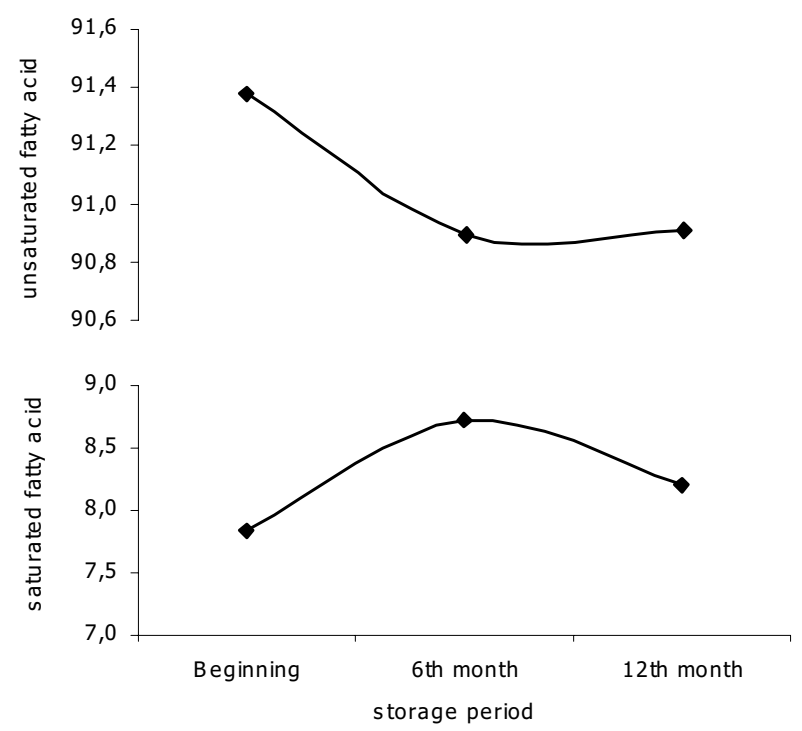

Figure 1

The Change of Total Saturated and Unsaturated Fatty Acid Contents of Hazelnut Cultivars During the Storage (\%).

unsaturation of fatty acids and an increase in hexanal and octanel derived from linoleate rather than oleate, were observed in hazelnuts during storage at room temperature. Both the linoleic acid and, to a certain extent, oleic acid are at a high risk of peroxidation. Oxidation of polyunsaturated fatty acids which occurs in almond seeds during long term storage arises from the observation that the proportion of polyunsaturated fatty acids diminishes throughout ageing (Zacheo et al., 2000). Although all values for fatty acids were relative, observed differences were interpreted as being the result of destruction or oxidation and subsequent loss of fatty acids, proportional increases in palmitic, stearic and oleic acid were deemed to be the effects of decreases in other fatty acids ( Maskan and Karatas, 1998).

The unsaturated fatty acid content of hazelnuts makes them nutritional products, but also makes them more susceptible to autoxidation. It is necessary to know the chemical and fatty acid composition of hazelnuts and the change of these parameters during the storage period because of their relationship to nutrition and oxidation (Hsieh and Kinsella, 1989

\section{REFERENCES}

Agar IT, Kafkas S, Balikçi Ö. 1995. Türk findik çesitlerinin derim zamaninda, iç ve kabuklu halde sogukta depolandiktan sonra yag içerikleri ve yag asitleri karakteristikleri. In 'Türkiye II. Ulusal Bahçe Bitkileri Kongresi', pp. 449-504, Adana.

Anonymous.1978. T.S.E. Iç findik standardi, p. 13, T.S. 3075, Ankara.
AOAC 2000. Official Methods Of Analysis Of AOAC International. Section 40, p.1. Maryland, USA.

Ebrahem KS, Richardson DG, Tetley RM, Mehlenbacher SA. 1994. Oil content, fatty acid composition and vitamin $E$ concentration of 17 hazelnut varieties, compared to other types of nuts and oils seeds. Acta Horticulture, 351, 685-692.

FAO. 2003. Production Yearbook. FAO, Rome.

Fraser GE, Sabate J, Beeson WL, Strahan TMA. 1992. Possible protective effect of nut consumption on rick of coronary heart disease. Arch Int Med., 152, 1416-1424.

Garcia JM, Agar IT, Streif J. 1994. Lipid characteristics of kernels from different hazelnut varieties. Turkish Journal of Agriculture and Forestry, 18, 199-202.

Hsieh RJ, Kinsella JE. 1989. Oxidation of polyunsaturated fatty acids. Adv. Food Nutr. Res., 43, 232-341.

Keme T, Messerli M, Shejbal J, Vitali F. 1983a. The storage of hazelnuts at room temperature under nitrogen (I). Rev. Choc. Confect. Bakery, 8, 24-28.

Keme T, Messerli M, Shejbal J, Vitali F. 1983b. The storage of hazelnuts at room temperature under nitrogen (II). Rev. Choc. Confect. Bakery, 8, 15-20.

Kinderlerer, J.L., Stuart, J. (1992). Rancidity in hazelnuts due to volatile aliphatic aldehydes. Journal of Science of Food and Agriculture, 58, 89-93.

Koyuncu MA, Koyuncu F, Bostan SZ, Islam A. 1997. Change of fat content and fatty acid composition during the fruit development period in the hazelnuts Tombul and Palaz cultivars grown in Ordu. Acta Horticulturae, 45, 229-233.

Koyuncu MA 2004. Change of fat content and fatty acid composition of Turkish hazelnuts (Corylus avellana L.) during the storage. Journal of Food Quality, 27, 304-309.

Maskan M, Karatas S. 1998. Fatty acid oxidation of pistachio nuts stored under various atmospheric conditions and different temperatures. J Sci Food Agric, 77, 334-340.

Özdemir M, Açkurt F, Kaplan M,Yildiz M, Löker M. 2001. Evaluation of new Turkish hybrid hazelnut (Corylus avellana L.) varieties: fatty acid composition, -tocopherol content, mineral composition and stability. Food Chemistry, 73, 411-415.

Parcerisa J, Richardson DG, Rafecas M, Codony R, Boatella J. 1998. Fatty acids, tocopherol and sterol content of some hazelnut varieties (Corylus avellana L.) harvested oregon (USA). Journal of Chromatography A, 805, 259-268.

Pekmezci M. 1983. Plastik torbalarda ambalajlanan findiklarin muhafazasi üzerine degisik depo kosullarinin etkisi. In 'Türkiye Bahçe Ürünlerinin Depolanmasi, Pazara Hazirlanmasi ve Tasinmasi Sempozyumu', pp.234-249, Adana.

Savage GP, McNeil, DL. 1998. Chemical composition of hazelnut (Corylus avellana L.) grown in New Zealand. International Journal of Food Sciences and Nutrition, 49, 199-203.

Zacheo G, Cappello MS, Gallo A, Santino A, Cappello AR 2000. Changes associated with post-harvest ageing in almond seeds. Lebensm.-Wiss. U.-Technol., 33, 415-423. 